\title{
Stem Education: How much integration is enough?
}

\author{
Thomas G. Barclay ${ }^{\mathrm{a}}$, Brendan Bentley ${ }^{\mathrm{b}} *$ \\ a tom.barclay@adelaide.edu.au \\ ${ }^{\mathrm{a} b}$ School of Education, University of Adelaide, Adelaide, Australia
}

\begin{abstract}
STEM Education has in recent years has been influenced by both political and pedagogical imperatives to increase student participation and improve student learning in Science, Technology, Engineering and Mathematics (STEM) Education. Integrated approaches to STEM Education have been identified to increase student engagement in STEM Education and lead to improved depth of understanding of STEM concepts. Nonetheless, such integrated approaches require significant understanding from engaged, skilled an appropriately trained teachers from multiple disciplines to work effectively. This paper investigates the conceptual and philosophical rationales for integrating STEM Education and provides a summary of both pedagogically and structural considerations that may assist schools in implementing an integrated approach to STEM Education.
\end{abstract}

Keywords: STEM education; integrated education; inquiry-based learning; integrative review methodology

\section{Introduction}

Building capacity in Science, Technology, Engineering and Mathematics (STEM) through improved STEM Education is seen as key both for Australian students to have a future of productive employment (Education Council, 2015) and for Australia to compete in the global economy (Marginson, Tytler, Freeman, \& Roberts, 2013; Office of the Chief Scientist, 2014). Other governments as well as Australia have priorities in STEM Education (Barlex, 2011; Becker \& Kyungsuk, 2011; Blackley \& Howell, 2015; Breiner, Harkness, Johnson, \& Koehler, 2012; Chubb, 2015; Marginson et al., 2013; Ritz \& Fan, 2015; U.S. Department of Education, 2007; Williams, 2011) and in particular the education systems of Britain and the US have similar motivations promoting STEM Education as in Australia and are approaching the implementation of STEM Education using similar strategies (Blackley \& Howell, 2015; Williams, 2011). 
The more recent and significant upshift in momentum to build STEM capacity and promote STEM within educational settings has heightened the urgency for change. The recent interest in the concept of STEM Education has gained traction and is now favoured by many educators, education researchers, education bureaucrats and politicians, who are attracted by the learning and political opportunities provided by the amalgamation of the disciplines and the focus on technological innovation.

This momentum shift is in part indicative of the broader changes found in STEM Education and in particular the pedagogical strategies used to teach STEM. This changing pedagogical landscape remains contested. Although at times politically driven, some researchers suggest that some STEM strategies are often too broad and imprecise to be effectively applied to school curricula (Blackley \& Howell, 2015; Williams, 2011). There remains much debate in the literature. How STEM is defined in the context of education, what STEM Education currently is, what it should be in the future (Breiner et al., 2012; Bybee, 2013; Moore et al., 2014; Sanders, 2009; Vasquez, 2014) and how to teach STEM Education (Lehrer \& Schauble, 2021) all remain contested.

The following four questions are used to inform this paper;

1) what are the significant theoretical understandings underpinning contemporary STEM Education teaching theory,

2) how effective is the use of STEM problem-based/project tasks in optimising student learning,

3) what level of integration is required for successful student learning and

4) is there any distinguishing benefit to student learning when teaching is delivered by an individual or teamteaching approach?

The paper provides through an integrative review of STEM and STEM Education literature an overview of the contemporary pedagogical practices associated with STEM Education. The review begins with investigating the general understanding and theoretical underpinnings of STEM Education and proceeds to investigate the benefits of adopting problem-based/project tasks and differing iterations of discipline integration considered to be appropriate for STEM Education. An analysis of literature underpinning any distinguishing benefit to student learning when teaching is delivered by an individual or team-teaching approach is undertaken along with a summary of both pedagogically and structural considerations that may assist schools in implementing an integrated approach to STEM Education are highlighted.

\section{Methods}

An integrative review was chosen as the most appropriate methodology to investigate the four questions interrogated in this study. Central to integrative reviews is both the synthesising of literature to construct new 
theoretical understandings and perspectives (Torraco, 2005) and the re-conceptualization of previous knowledge to create novel theoretical models (Snyder, 2019). Although other review methodologies such as narrative reviews have been used in past STEM Education research (Minichiello, Hood, \& Harkness, 2018; Simpson \& Bouhafa, 2020), an integrative review supports and caters the authors goal of limited peerreviewed literature to better inform teachers in the nascent area of STEM Education. The authors, to reduce researcher bias, adopted several criteria recommended by other researchers who have undertaken research using similar review methodologies (Ferrari, 2015; Green, Johnson, Adams, 2006) and embraced a commentary approach to provoke further contemplations and established a series of specific research questions to guide and direct the research.

\section{Discussions}

3.1 A brief overview of the current debate

A significant area of debate within the literature challenges the number of STEM disciplines required for the STEM label to apply (Pitt, 2009). This interrogation also incorporates the level of inclusivity of each of the STEM disciplines (Vasquez, Sneider, \& Comer, 2013), with some arguing that a Science, and sometimes Mathematics, focus in STEM variously neglects learning in Mathematics (English, 2016; Honey, Pearson, \& Schweingruber, 2014), technology (Barlex, 2011; Williams, 2011) or engineering (Blackley \& Howell, 2015; English, 2016).

3.2 Integrated STEM Education a common approach?

Integrated STEM Education eliminates the barriers between the individual disciplines by drawing on methods, knowledge and skills from multiple disciplines, often using collaborative work to solve real-world problems so the learning is meaningful and relevant to students (Moore et al., 2014; Sanders, 2009; Vasquez et al., 2013). A number of reports emphasise the importance of the integration of STEM Education (English, 2016; Honey et al., 2014; Stohlmann, Moore, \& Roehrig, 2012; Wang, Moore, Roehrig, \& Park, 2011) as the disciplines are not isolated in real-world occupations (Breiner et al., 2012; Moore et al., 2014; Sanders, 2009). Further, a positive influence of integrated STEM Education on student attitudes, understanding and achievement has been identified in reviews of the subject (Becker \& Kyungsuk, 2011; Yildirim, 2016) and educators propose that taking an integrated approach to STEM education will provide some pedagogical rigour to the political agenda for STEM Education (Blackley \& Howell, 2015).

3.3 Integrated STEM Education and Educational Theory 
Integrated education in part comes from the progressive education movement which focussed on studentcentred experiential learning using authentic tasks, naturally integrating curricula based on thematic units (Dewey, 1933). This approach employed many of the aspects prized in integrated STEM Education, including, problem solving, critical and creative thinking and collaborative learning projects (Hartzler, 2000; Moore \& Smith, 2014). The progressive education movement also introduced the idea that students should learn content just-in-time to be applied to an authentic task, building motivation and enjoyment in the act of learning (Dewey, 1933).

More recently, these teaching methods have been adopted into constructivist and social constructivist theories of education because the inventive activities assist students to make connections between their own prior knowledge and the new experience, helping to develop understanding in the student (Blackley \& Howell, 2015; Green, Piel, \& Flowers, 2008; Piaget, 1973; Roth, 2001). Further, the engaging and collaborative nature of the tasks builds intrinsic motivation, encouraging students to be active contributors to their own learning (Piaget, 1973; Roth, 2001; Schnittka \& Bell, 2011). This suggests that Inquiry-based Learning (IBL) is seen as a valuable component of effective integrated STEM Education (Bissaker, 2014) and in the implementation of integrated STEM, education teachers perceived that IBL was key to making the process work (Wang et al., 2011).

Despite the positivity of integrating STEM education from the constructivist viewpoint, there is a body of evidence suggesting open-ended inquiry frequently exploited in integrated STEM education is not as effective or efficient in developing student learning as direct instruction due to a lack of student guidance (Almarode, Subotnik, \& Lee, 2016; Kirschner, Sweller, \& Clark, 2006). This is based on cognitive theories that propose students with insufficient foundational knowledge can be overloaded with novel information during problem-solving (Sweller, 2011). Such a scenario overburdens the working memory and prevents effective storage of information in long-term memory (Schweppe \& Rummer, 2014; Sweller, 2011), resulting in a detrimental effect on student learning (Kirschner et al., 2006). Support for these ideas comes from reports that found direct instruction was preferred to collaborative work when building foundational knowledge for STEM (Almarode et al., 2016) and that simple retrieval practice produced more learning than more elaborative work (Karpicke \& Blunt, 2011), though the methods of the later report were debated in a published rebuttal (Mintzes et al., 2011).

3.4 The benefits of an integrated approach

To explain the dichotomy in the analysis of the effectiveness of integrated STEM Education a recent metaanalysis of the effectiveness of problem-based learning is used that showed an integrated approach actually 
increased student performance (Hattie, 2015; Lazonder \& Harmsen, 2016), but with limited effectiveness with an effect size of 0.12 based on 1200 studies (Hattie, 2015).

The limited effectiveness of an integrated approach was attributed to the idea mentioned above in that some teachers present students with the problems for which they have too little background knowledge to effectively solve. Contrastingly, also considered important was that some teachers present problems that are too highly structured, and students had insufficient opportunity to experiment (Hattie, 2015). This importance of the teacher in the effective delivery of problem-based learning confirms a previous review that showed a strong positive effect size (0.54) on academic achievement for cooperative IBL but a negative effect size of 0.74 when the task was conducted with non-expert tutors (Norman \& Schmidt, 2000).

This evidence indicates that to apply integrated STEM Education effectively, careful consideration of the ideas of both pedagogies of constructivism and cognitivism are required to simultaneously provide sufficient background knowledge but still challenge students (Bentley 2020; English, King, \& Smeed, 2017; Green et al., 2008; Kolb, 2014; Lazonder \& Harmsen, 2016; Schnittka \& Bell, 2011; Zubrowski, 2002). This dichotomy of issues also highlights the common perception that many teachers require further training to get the best student learning using inquiry-based methods (Cotner, Loper, Walker, \& Brooks, 2013; Sanders, 2009; Stohlmann et al., 2012).

More evidence that the effective implementation of integrated STEM requires a balance between constructivist and cognitivist ideas is that many aspects of integrated STEM Education sit within the sociocognitive research movement (Moore \& Smith, 2014) and there are cognitive themes that align with integrated STEM Education (Bruning, Schraw, Norby, \& Ronning, 2004; Sanders, 2009). For example, conceptual change theory is a cognitivist idea that recognises that students often have alternative conceptions to the accepted scientific ones that can be difficult to change depending on the compatibility of old and new conceptions (Chi, Slotta, \& De Leeuw, 1994; Wiggins \& McTighe, 2005). Conceptual change is best achieved by providing concrete, visual examples, through experimental approaches or by problem-solving, all of which are important aspects of integrated STEM Education (Schnittka \& Bell, 2011). This method also aligns with guided constructivism that exploits hands-on interaction with artefacts that give students a tangible representation of abstract concepts, allowing invention of personal meaning to construct new understanding (Green et al., 2008) and assist deeper understanding of scientific and technical concepts (Green et al., 2008; Roth, 2001).

Balancing these educational ideas and instituting close collaboration between disciplines is complex and necessitates more intellectual engagement from the teacher (Langley \& Guzey, 2014) to develop well thought out learning goals (Wiggins \& McTighe, 2005). This means that compared to traditional teaching 
methods, to successfully implement integrated STEM Education teachers require more planning time (Sanders, 2009; Vasquez, 2014), preparation time (ACARA, 2016; Waldrop, 2015) and training (Brooks \& Solheim, 2014; Cotner et al., 2013).

\subsection{Cognition and integration of STEM Education}

Neuroscience and cognitive psychology research are increasing our understanding of how learning alters the structure of the brain and how humans organise knowledge to solve problems (Bransford et al., 2000; Schweppe \& Rummer, 2014; Sweller, 2011). For example, researchers now understand key principles on how to structure learning that enables students to use their knowledge and skills in new settings (Bransford et al., 2000). For integrated learning and the transfer of knowledge to new contexts, students require a foundation of factual knowledge, not just simple memorisation of disconnected facts, but a deep conceptual understanding that organises the knowledge around the original context (Bransford et al., 2000; Gardner, 1991). The conceptual framework then assists in applying the knowledge to the new context. This idea means that teachers should abandon the idea of complete and equal superficial coverage of extensive curriculum and choose areas to develop a deep understanding in students of defining concepts that can then be transferred to areas with less focussed coverage (Bransford et al., 2000; Wiggins \& McTighe, 2005).

Integrated STEM Education is generally acknowledged to be engaging to students, which can be exploited to improve student learning in two keyways. Firstly, cognitivist neuroscience suggests that integrated STEM Education employed using well designed Inquiry-based learning (IBL) both arouses and maintains student interest by activating their 'focus' through the importance and relevance of the task to the student and the novelty of the problems. This is part of the brains system to concentrate on significant information at the expense of the trivial (Schunk, 2012). This 'focus' provides structure to the incoming information to allow storage in the working memory and the creation of appropriate links to previous knowledge to assist consolidation of the neural connections such that the knowledge can be retained long term (Schunk, 2012). Secondly, collaboration in problem solving shows students different ways that the information can be combined with other knowledge and applied, forming new neuronal connections that are further extended by the increased emotional involvement of the student due to the social interactions to create extensive neural networks (Schunk, 2012). Collaboration is also important socially as the best student learning occurs in collaborative classroom communities that support students to push their understanding by allowing for and indeed valuing mistakes. It is these processes that reveal student understanding so teachers can link new understanding to that knowledge (Bransford et al., 2000). 
IBL provides a platform for social and collaborative learning and is also associated with problem solving in educational settings. IBL is adopted to encourage and develop student metacognition (HmeloSilver, 2004). Such metacognitive approaches to instruction use student self-assessment of their own understanding and reflection of where improvement is required to assist in their development of deep conceptual understanding (Schunk, 2012). Such student metacognition also assists students to transfer knowledge to new contexts (Bransford et al., 2000; Pintrich, 2002) and helps them to understand their strengths and weaknesses and so tailor their own approach to learning enabling them to become effective selfdirected learners (Bransford et al., 2000; Pintrich, 2002).

\subsection{Implementation of Integrated STEM Education}

The adoption of IBL when using an integrated approach to teach STEM Education supports the application of authentic tasks using the connections between disciplines to come up with solutions, with facilitation and guidance by teachers rather than direct instruction (Schnittka \& Bell, 2011; Stohlmann et al., 2012). When implementing IBL, as mentioned in the previous section, students need sufficient background understanding, teachers must provide the appropriate level of guidance and the task should require application and transfer of knowledge and skills rather than simple regurgitation. To achieve this, students new to integrated STEM Education may require explicit instruction in problem solving (Sidawi, 2009) and transparent and explicit implementation of integration to assist students to make the connections between disciplines (English, 2016). This helps to ensure the right balance of scaffolding and extension of the students for effective learning to occur (Green et al., 2008; Hattie, 2015; Schnittka \& Bell, 2011).

Several additional themes were found within the literature that requires consideration and may further assist the successful implementation of an integrated approach to STEM Education. These additional themes are explored in the following sections.

\subsection{Establish and Build upon Prior Student Learning}

The importance of prior learning to the transfer of knowledge based on neuroscience and the benefits of metacognition discussed above has strong alignment with constructivist theorists such as Piaget (Piaget, 1973) and Vygotsky (Vygotsky, 1978) that state humans construct new knowledge and understandings from the basis of what they already know and believe (Bransford et al., 2000). This means teachers must be very clear about the prior learning and preconceptions of the students and engage those understandings to present new concepts otherwise it is unlikely that students will build a deep understanding of the new concepts (Bransford et al., 2000). To do this, teachers should employ ongoing formative assessment to make student thinking 
visible to both teachers and the students themselves (Bransford et al., 2000). Further, classrooms must be learner-centred with teachers that clearly understand the knowledge of their students such that they can present students with tasks that fall within their zone of proximal development (Vygotsky, 1978).

\subsection{Linked Silos or Integrated Teaching}

Correlation teaching, or multidisciplinary teaching based on the Vasquez model (Vasquez et al., 2013), is a basic level of integration in which teachers seek to teach related areas at the same time in separate classes so as to assist students to make connections between subjects. However, transfer of knowledge by students rarely works using this method (Hartzler, 2000; Vars, 1991). Higher levels of integration that apply knowledge and skills from multiple subjects to achieve the integrated goal are preferable to promote the connections between disciplines desired in integrated education (Hartzler, 2000; Vars, 1991).

\subsection{Integrated Teaching Individually or in Teams}

A single teacher may use an integrated approach to teach the subjects they are qualified for (Hartzler, 2000; Vars, 1991) but teachers rarely have qualifications in all of Science, Mathematics and Design and Technology. Consequently, single teachers are likely to favour their own subjects in this process and it has been demonstrated that teachers generally don't have the pedagogical skill or content knowledge to successfully integrate a subject from outside their own area of expertise (Nichols \& Davies, 2006). Accordingly, if a single discipline is running STEM like tasks within their own curriculum, resources and timetable without input from other disciplines then this approach is reasonable, but perhaps is not really integrated STEM Education.

In the majority of cases, integrated learning requires close collaboration among STEM teachers where the complementary knowledge of the team members makes up for individual short comings (Nichols \& Davies, 2006; Sanders, 2009). Often this means all teachers collaborate on curriculum design and contribute to the teaching. This may occur separately, with each teacher taking classes on their own, or true team teaching may be used. Team teaching where teachers from multiple disciplines come together to teach combined cohorts of classes is preferable because their diverse expertise can be applied as necessary during each lesson (Hartzler, 2000; Vars, 1991). The next step on the continuum of integration is the total staff approach in which all teachers from all subjects (not just STEM) relate their content to particular themes (Bissaker, 2014; Hartzler, 2000; Vars, 1991). Using this approach further complicates the process of matching content to the year level requirements set by school authorities (Hartzler, 2000; Vars, 1991) and to link each of the subjects (English, 2016; Honey et al., 2014; Williams, 2011). As such, smaller groups of teachers 
contributing to integrated STEM Education allows teachers not interested in the pedagogy or with content not well matched to the theme to opt out, hopefully resulting in enthusiastic contributing teachers motivated for the program to succeed (Hartzler, 2000; Vars, 1991).

\subsection{STEM Education Task Construction}

The Australian Curriculum and Reporting Agency (ACARA) prioritises IBL through design tasks. The construction of design tasks sympathetic to IBL should be a key aspect of the integration of STEM Education in Australia. Those design tasks will define a problem for the students to solve (Vasquez, 2014) that authentically uses skills and knowledge from the STEM disciplines (and other disciplines) (Moore \& Smith, 2014) and will achieve learning goals for those disciplines.

- $\quad$ The problem chosen should have real world context and relevance to engage students (Moore \& Smith, 2014; Moore et al., 2014; Stohlmann et al., 2012).

- $\quad$ The task should then be constructed upon foundational knowledge and skills the students already have (Sidawi, 2009) so students can effectively apply what they know to a new context and make educated predictions (Sidawi, 2009; Zubrowski, 2002).

- This design task should have sufficient complexity to encourage the students to plan and execute a resolution to the problem collaboratively (Moore \& Smith, 2014; Moore et al., 2014).

- $\quad$ The complexity also encourages iterative design in which the students create-test-refine and learn from their failures (Cobb, Confrey, diSessa, Lehrer, \& Schauble, 2003; English et al., 2017; Vasquez, 2014).

When such tasks are appropriately implemented, students develop technical skills, core understanding of engineering design and scientific enquiry and learn STEM disciplinary knowledge (Moore et al., 2014).

Despite the importance of foundational knowledge established in the previous section, for simpler challenges it may be valuable to allow students the opportunity to perform the design challenge first in an open exploration (Zubrowski, 2002). Even in this case, the teacher must ensure students have developed the thought processes that allow them to proceed in their design using a scientific process and test their design in a systematic way such that they can use their experimental results to inform their investigation. After this exploration, the teacher now has context to deliver the theories behind the experiment and armed with new knowledge the students can then be given an opportunity to improve their design (Zubrowski, 2002). This 
process can foster understanding of the design process and the underlying theories (Zubrowski, 2002) and so allow students to build knowledge and comprehend the connections between disciplines (Stohlmann et al., 2012).

\section{Conclusion}

Science and technology research has always been a multidisciplinary pursuit and this is emphasised by emerging meta-disciplines such as nanotechnology and biotechnology (Nichols \& Davies, 2006). As such, teaching in the silos of the traditional disciplines is out of step with the methods of contemporary scientists, and it is difficult for students to comprehend new science and technology without crossing the boundaries between disciplines (Furner \& Kumar, 2007; Moore et al., 2014; Nichols \& Davies, 2006; Stohlmann et al., 2012). This includes many of the scientific and technological problems today's society faces; from dealing with global warming to addressing antibiotic resistance and providing new and better products for the industries that employ the population (Chubb, 2015).

While this study is limited to reviewing specific literature within the parameters of an integrative review approach further research to explore in detail other STEM teaching models should be encouraged. Especially as the current enthusiasm for STEM Education is not just a passing novelty interest by the Australian Federal Government (Office of the Chief Scientist, 2013), but has been increasingly on the worldwide educational agenda for more than 20 years (National Science Board, 2007; National Science Foundation, 1996). The Australian Federal Governments vision for the best ways of increasing participation and performance in STEM Education are to apply integrated learning approaches to STEM Education using IBL (Department of Industry and Science, 2015; Marginson et al., 2013; Office of the Chief Scientist, 2013, 2014) These factors combined mean that some level of integrated STEM Education should be an essential part of Australian schools implementation of Science, Design and Technology and Mathematics Education but a decision needs to made around how much integration is best for student learning in the context of a particular school.

While complete integration of STEM Education is not in many cases practical schools must also take into account the limited positive influence of integrated STEM learning on student outcomes (Becker \& Kyungsuk, 2011; Hattie, 2015; Lazonder \& Harmsen, 2016). Benefits to schools adopting at least a partially integrated STEM Education curriculum do go beyond student performance, other benefits do exist. While there is some debate over whether the current STEM skills shortage stated in government reports (Marginson et al., 2013; National Academy of Sciences et al., 2007; Office of the Chief Scientist, 2014) is real in the Australian context (Education Council, 2018; Panizzon, Corrigan, Forgasz, \& Hopkins, 2015), Australian 
employers value the adaptable generic skills and characteristics of STEM skilled employees such as critical and creative thinking, innovation, collaboration and communication (Hartzler, 2000; Moore \& Smith, 2014), even outside STEM specific occupations (English et al., 2017).

Accordingly, in pursuing a partially integrated STEM curriculum schools can not only expose students to an engaging STEM Education that may inspire some students to follow STEM career paths, but also be of value to the future of all students in the way they comprehend the world.

\section{References}

Australian Curriculum and Reporting Agency. (2016). ACARA STEM Connections Project Report. https://www.australiancurriculum.edu.au/media/3220/stem-connections-report.pdf.

Almarode, J., Subotnik, R., \& Lee, G. M. (2016). What Works. Gifted Child Today, 39(4), 185-190. doi: papers3://publication/doi/10.1177/1076217516662096

Alton-Lee, A. (2003). Quality Teaching for Diverse Students in Schooling: Best Evidence Synthesis. Wellington, NZ.

Balyer, A., \& Gunduz, Y. (2012). Effects of Structured Extracurricular Facilities on Students' Academic and Social Development. Procedia - Social and Behavioral Sciences, 46, 4803-4807. doi: papers3://publication/doi/10.1016/j.sbspro.2012.06.338

Barlex, D. (2011). The Stem Programme in England Positioning Technology Education in the Curriculum (pp. 63-74). Rotterdam: SensePublishers.

Becker, K., \& Kyungsuk, P. (2011). Effects of integrative approaches among science, technology, engineering, and mathematics (STEM) subjects on students' learning: A preliminary meta-analysis. Journal of STEM Education: Innovations \& Research, 12(5/6), 23-37.

Bentley, B. (2020). New Understandings of Instructional Theory: Finding the Instructional Sweet Spot. In M. White \& F. McCallum (Eds.), Critical Perspectives on Teaching, Learning and Leadership: Enhancing Educational Outcomes (pp. 107-122).Springer.

Bissaker, K. (2014). Transforming STEM Education in an Innovative Australian School: The Role of Teachers' and Academics' Professional Partnerships. Theory Into Practice, 53(1), 55-63. doi: papers3://publication/doi/10.1080/00405841.2014.862124

Blackley, S., \& Howell, J. (2015). A STEM Narrative: 15 Years in the Making. Australian Journal of Teacher Education, 40(7), 102-112. doi: papers3://publication/doi/10.14221/ajte.2015v40n7.8

Blackmore, J., Bateman, D., Loughlin, J., O'Mara, J., \& Aranda, G. (2011). Research into the connection between built learning spaces and student outcomes. Melbourne, Vic: State of Victoria (Department of Education and Early Childhood Development) http://dro.deakin.edu.au/eserv/DU:30036968/blackmore-researchinto-2011.pdf. 
Bransford, J. D., Brown, A. L., Cocking, R. R., Donovan, M. S., Bransford, J. D., \& Pellegrino, J. W. (Eds.). (2000). How People Learn: Brain, Mind, Experience, and School: Expanded Edition. Washington, DC: National Academies Press.

Breiner, J. M., Harkness, S. S., Johnson, C. C., \& Koehler, C. M. (2012). What Is STEM? School Science and Mathematics, 112(1), 3-11. doi: papers3://publication/doi/10.1111/j.1949-8594.2011.00109.x

Brooks, D. C., \& Solheim, C. A. (2014). Pedagogy Matters, Too: The Impact of Adapting Teaching Approaches to Formal Learning Environments on Student Learning. In P. Baepler, D. C. Brooks \& J. D. Walker (Eds.), Active Learning Spaces: New Directions for Teaching and Learning (pp. 53-61). Somerset, U.S: John Wiley \& Sons, Incorporated.

Bruning, R. H., Schraw, G. J., Norby, M. M., \& Ronning, R. R. (2004). Cognitive psychology and instruction (4th ed.): Pearson.

Bybee, R. W. (2013). The case for STEM education: challenges and opportunities. Arlington, VA: National Science Teachers Association.

Carnwell, R., \& Daly, W. (2001). Strategies for the construction of a critical review of the literature. Nurse Education in Practice, 1(2), 57-63. doi: https://doi.org/10.1054/nepr.2001.0008

Chi, M. T. H., Slotta, J. D., \& De Leeuw, N. (1994). From things to processes: A theory of conceptual change for learning science concepts. Learning and Instruction, 4(1), 27-43. doi: https://doi.org/10.1016/0959-4752(94)90017-5

Chubb, I. (2015). Address to the National Press Club: Aspiring to something magnificent. Canberra, Australia: Office of the Chief Scientist. http://www.chiefscientist.gov.au/2015/03/keynote-addressto-the-national-press-club-for-science-meets-parliament-2/.

Cobb, P., Confrey, J., diSessa, A., Lehrer, R., \& Schauble, L. (2003). Design experiments in educational research. Educational Researcher, 32(1), 9-13.

Cooper, H. M. (1988). Organizing knowledge syntheses: A taxonomy of literature reviews. Knowledge in Society, 1(1), 104. doi: 10.1007/BF03177550

Cotner, S., Loper, J., Walker, J. D., \& Brooks, D. C. (2013). It's Not You, It's the Room - Are the High-Tech, Active Learning Classrooms Worth It? Journal of College Science Teaching, 42(6), 82-88. doi:papers3://publication/doi/10.2307/43632160

Department of Industry and Science. (2015). Vision for a Science Nation. Responding to Science, Technology, Engineering and Mathematics: Australia's Future. Canberra, ACT.: Commonwealth of Australia.

Dewey, J. (1933). Dewey Outlines Utopian Schools, New York Times. https://search-proquestcom/docview/100732385?accountid=8203 
Education Council. (2015). National STEM School Education Strategy 2016-2026. http://www.scseec.edu.au/site/DefaultSite/filesystem/documents/National\%20STEM\%20School\%20 Education\%20Strategy.pdf.

Education Council. (2018). Optimising STEM industry school partnerships: inspiring Australia's next generation. Melbourne, Vic: Education Services Australia.

English, L. D. (2016). STEM education K-12: perspectives on integration. International Journal of STEM Education, 3(1), 1-8. doi: papers3://publication/doi/10.1186/s40594-016-0036-1

English, L. D., King, D., \& Smeed, J. (2017). Advancing integrated STEM learning through engineering design: Sixth-grade students' design and construction of earthquake resistant buildings. The Journal of Educational Research, 110(3), 255-271. doi: papers3://publication/doi/10.1080/00220671.2016.1264053

Ferrari, R. (2015). Writing narrative style literature reviews. Medical Writing, 24(4), 230-235.

Furner, J. M., \& Kumar, D. D. (2007). The Mathematics and Science Integration Argument: A Stand for Teacher Education. Eurasia Journal of Mathematics, Science and Technology Education, 3(3), 185189. doi: papers3://publication/uuid/7ACB2F9B-8826-4874-BBDA-EE23B65158E3

Gardner, H. (1991). The unschooled mind: How children think and how schools should teach. New York, NY: Basic Books.

Glass, G. V. (1976). Primary, secondary, and meta-analysis of research. Educational Researcher, 5(10), 3-8. doi: papers3://publication/doi/10.1177/EDRA_5_10;wgroup:string: SAGE.

Green, B. N., Johnson, C. D., \& Adams, A. (2006). Writing narrative literature reviews for peer-reviewed journals: Secrets of the trade. Journal of Chiropractic Medicine, 5(3), 101-117.

Green, M., Piel, J. A., \& Flowers, C. (2008). Reversing Education Majors' Arithmetic Misconceptions With Short-Term Instruction Using Manipulatives. The Journal of Educational Research, 101(4), 234-242. doi: 10.3200/JOER.101.4.234-242

Hartzler, D. S. (2000). A meta-analysis of studies conducted on integrated curriculum programs and their effects on student achievement. (Doctor of Education), Indiana University, Indiana, IN.

Hattie, J. A. C. (2015). The applicability of Visible Learning to higher education. Scholarship of Teaching and Learning in Psychology, 1(1), 79-91. doi: papers3://publication/doi/10.1037/st10000021

Hmelo-Silver, C. E. (2004). Problem-Based Learning: What and How Do Students Learn? Educational Psychology Review, 16(3), 235-266. doi: 10.1023/B:EDPR.0000034022.16470.f3

Honey, M., Pearson, G., \& Schweingruber, H. (2014). STEM integration in K-12 education: Status, prospects, and an agenda for research. Washington DC.: The National Academic Press. https://pdfs.semanticscholar.org/bac5/69ca108d7ac7c96574826419074316150060.pdf

Kaminstein, D. (2017). Writing A Literature Review For An Applied Master's Degree. Organizational Dynamics Working Papers, 23, 1-13. 
Karpicke, J. D., \& Blunt, J. R. (2011). Retrieval Practice Produces More Learning than Elaborative Studying with Concept Mapping. Science, 331(6018), 772.

Kirschner, P. A., Sweller, J., \& Clark, R. E. (2006). Why Minimal Guidance During Instruction Does Not Work: An Analysis of the Failure of Constructivist, Discovery, Problem-Based, Experiential, and Inquiry-Based Teaching. Educational Psychologist, 41(2), 75-86. doi: 10.1207/s15326985ep4102_1

Kolb, D. A. (2014). Experiential Learning: Experience As the Source of Learning and Development (2nd ed). Upper Saddle River, New Jersey: Pearson FT Press.

Langley, D., \& Guzey, S. S. (2014). Conducting an Introductory Biology Course in an Active Learning Classroom: A Case Study of an Experienced Faculty Member. In P. Baepler, D. C. Brooks \& J. D. Walker (Eds.), Active Learning Spaces: New Directions for Teaching and Learning (Vol. 2014, pp. 71-76). Somerset, US: John Wiley \& Sons, Incorporated.

Lazonder, A. W., \& Harmsen, R. (2016). Meta-Analysis of Inquiry-Based Learning: Effects of Guidance. Review of Educational Research, 86(3), 681-718. doi: papers3://publication/doi/10.3102/0034654315627366

Lehrer, R., \& Schauble, L. (2021). Stepping Carefully: Thinking Through the Potential Pitfalls of Integrated STEM. Journal for STEM Educ Res 4, 1-26. https://doi.org/10.1007/s41979-020-00042-y

Marginson, S., Tytler, R., Freeman, B., \& Roberts, K. (2013). STEM: Country Comparisons. Australian Council of Learned Academies. https://acola.org.au/wp/PDF/SAF02Consultants/SAF02_STEM_\%20FINAL.pdf

Matchar, D. B., Patwardhan, M., Sarria-Santamera, A., \& Westermann-Clark, E. V. (2006). Developing a Methodology for Establishing a Statement of Work for a Policy-Relevant Technical Analysis. Rockville, MD.

Minichiello, A., Hood, J.R. \& Harkness, D.S. (2018). Bringing User Experience Design to Bear on STEM Education: A Narrative Literature Review. Journal for STEM Educ Res 1, 7-33. https://doi.org/10.1007/s41979-018-0005-3

Mintzes, J. J., Canas, A., Coffey, J., Gorman, J., Gurley, L., Hoffman, R., . . . Wandersee, J. H. (2011). Comment on "Retrieval Practice Produces More Learning than Elaborative Studying with Concept Mapping”. Science, 334(6055), 453.

Moore, T. J., \& Smith, K. A. (2014). Advancing the State of the Art of STEM Integration. Journal of STEM Education Innovations, 15(1), 5-9. doi: papers3://publication/uuid/E8A01C4B-4541-461A-B7B8EED82E2F0F09

Moore, T. J., Stohlmann, M. S., Wang, H. H., Tank, K. M., Glancy, A. W., \& Roehrig, G. H. (2014). Implementation and Integration of Engineering in K-12 STEM Education. In S. Purzer, J. Strobel \& M. E. Cardella (Eds.), Engineering in pre-college settings: Synthesizing Research, Policy, and Practices (pp. 35-59). West Lafayette, IN: Purdue University Press. 
National Academy of Sciences, National Academy of Engineering, \& Institute of Medicine. (2007). Rising Above the Gathering Storm: Energizing and Employing America for a Brighter Economic Future. Washington, DC: The National Academies Press.

National Science Board. (2007). A National Action Plan for Addressing the Critical Needs of the U.S. Science, Technology, Engineering, and Mathematics Education System.: N.S. Foundation. https://www.nsf.gov/pubs/2007/nsb07114/nsb07114.pdf.

National Science Foundation. (1996). Shaping the Future: New Expectations for Undergraduate Education in Science, Mathematics, Engineering, and Technology. Arlington, VA: N. S. Foundation.

Nichols, K. \& Davies, J. (2006). Teaching and Learning in the New Sciences: A case for interdisciplinary inquiry-based learning. In: Y. J. Lee, A. L. Tan \& B.T. Ho (eds), Conference 2006. Singapore: National Institute of Education.

Norman, G. R., \& Schmidt, H. G. (2000). Effectiveness of problem-based learning curricula: theory, practice and paper darts. Medical Education, 34(9), 721-728.

Office of the Chief Scientist. (2013). Science, Technology, Engineering and Mathematics in the National Interest: A Strategic Approach. Canberra, ACT: Australian Government.

Office of the Chief Scientist. (2014). Science, Technology, Engineering and Mathematics: Australia's Future. Canberra, ACT: Australian Government.

Panizzon, D., Corrigan, D., Forgasz, H., \& Hopkins, S. (2015). Impending STEM Shortages in Australia: Beware the 'Smoke and Mirrors'. Procedia - Social and Behavioral Sciences, 167, 70-74. doi: papers3://publication/doi/10.1016/j.sbspro.2014.12.644

Piaget, J. (1973). To understand is to invent: the future of education. New York, NY: Grossman Publishers.

Pintrich, P. R. (2002). The Role of Metacognitive Knowledge in Learning, Teaching, and Assessing. Theory Into Practice, 41(4), 219-225. doi: 10.1207/s15430421tip4104_3

Pitt, J. (2009). Blurring the boundaries-STEM education and education for sustainable development. Design and Technology Education: An International Journal, 14(1), 37-48. doi: papers3://publication/uuid/2DFAA82F-B2D5-4FB7-8534-2A00AE74E696

Ritz, J. M., \& Fan, S. C. (2015). STEM and technology education: international state-of-the-art. International Journal of Technology and Design Education, 1-23. doi: papers3://publication/doi/10.1007/s10798014-9290-z

Roth, W. M. (2001). Learning science through technological design. Journal of Research in Science Teaching, 38(7), 768-790. doi: 10.1002/tea.1031

Sanders, M. (2009). STEM, STEM Education, STEM mania. The Technology Teacher, 20-26. doi: papers3://publication/uuid/71D81EBE-F95D-4D70-9257-2765E9E2ED34 
Schnittka, C., \& Bell, R. (2011). Engineering Design and Conceptual Change in Science: Addressing thermal energy and heat transfer in eighth grade. International Journal of Science Education, 33(13), 18611887. doi: 10.1080/09500693.2010.529177

Schunk, D. H. (2012). Learning Theories: An Educational Perspective (6th ed.). Boston, MA: Pearson.

Schweppe, J., \& Rummer, R. (2014). Attention, Working Memory, and Long-Term Memory in Multimedia Learning: An Integrated Perspective Based on Process Models of Working Memory. Educational Psychology Review, 26(2), 285-306. doi: 10.1007/s10648-013-9242-2

Shulruf, B. (2010). Do extra-curricular activities in schools improve educational outcomes? A critical review and meta-analysis of the literature. International Review of Education, 56(5/6), 591-612. doi: papers3://publication/doi/10.1007/s11159-010-9180-x

Sidawi, M. M. (2009). Teaching science through designing technology. International Journal of Technology and Design Education, 19(3), 269-287. doi: 10.1007/s10798-007-9045-1

Simpson, A., \& Bouhafa, Y. (2020). Youths' and Adults' Identity in STEM: a Systematic Literature Review. Journal for STEM Educ Res 3, 167-194. https://doi.org/10.1007/s41979-020-00034-y

Snyder, H. (2019). Literature review as a research methodology: An overview and guidelines, Journal of Business Research, 104, 333-339, https://doi.org/10.1016/j.jbusres.2019.07.039.

Stohlmann, M., Moore, T., \& Roehrig, G. (2012). Considerations for Teaching Integrated STEM Education. Journal of Pre-College Engineering Education Research, 2(1), 28-34. doi: papers3://publication/doi/10.5703/1288284314653

Sweller, J. (2011). Cognitive Load Theory. In J. P. Mestre \& B. H. Ross (Eds.), Psychology of Learning and Motivation (Vol. 55, pp. 37-76): Academic Press.

Torraco, R. (2005). Writing integrative literature reviews: Guidelines and examples. Human Resource Development Review, 4(3), 356-367.

U.S. Department of Education. (2007). Report of the Academic Competitiveness Council. Washington, DC.: U.S. Department of Education.

Vars, G. F. (1991). Integrated curriculum in historical perspective. Educational Leadership, 49(2), 14.

Vasquez, J. A. (2014). STEM: Beyond the Acronym. Educational Leadership, 10-15. doi: papers3://publication/uuid/74C75BFF-54A7-4345-BBBC-4DF650835869

Vasquez, J. A., Sneider, C., \& Comer, M. (2013). STEM lesson essentials, grades 3-8: Integrating science, technology, engineering, and mathematics. Portsmouth, NH: Heinemann.

Vygotsky, L. S. (1978). Mind in society: the development of higher psychological processes. Cambridge: Harvard University Press.

Waldrop, M. M. (2015). The science of teaching science. Nature, 523, 272-274. doi: papers3://publication/uuid/591251D4-3D31-4F63-A990-26577B75FD8B 
Wang, H. H., Moore, T. J., Roehrig, G. H., \& Park, M. S. (2011). STEM integration: Teacher perceptions and practice. Journal of Pre-College Engineering Education Research, 1(2), 1-13. doi: papers3://publication/doi/10.5703/1288284314636

Wiggins, G., \& McTighe, J. (2005). Understanding by Design. Alexandria, VA: Association for Supervision \& Curriculum Development.

Williams, P. J. (2011). STEM education: Proceed with caution. Design and Technology Education: An International Journal, 16(1), 26-35. doi: papers3://publication/uuid/9FB6A004-AD5D-449B-AEB4FE17669BD0C2

Xiao, Y., \& Watson, M. (2017). Guidance on Conducting a Systematic Literature Review. Journal of Planning Education and Research, 0739456X17723971. doi: 10.1177/0739456X17723971

Yildirim, B. (2016). An Analyses and Meta-Synthesis of Research on STEM Education. Journal of Education and Practice, 7(34), 23-33. doi: papers3://publication/uuid/F46624A6-16C3-4DE8-97DE2652D36D2374

Zubrowski, B. (2002). Integrating science into design technology projects: Using a standard model in the design process. Journal of Technology Education, 13(2), 48-67. doi: papers3://publication/doi/10.21061/jte.v13i2.a.4 